\title{
The exocrine glands of swarming females and physogastric queens of Cornitermes cumulans (Kollar) (Isoptera, Termitidae, Nasutitermitinae)
}

\author{
Ana Cristina Ignatti ${ }^{1}$ \\ Ana Maria Costa-Leonardo ${ }^{1}$
}

\begin{abstract}
The histological study of the exocrine glands in the swarming females showed the presence of tergal glands, mandibular glands, salivary glands and sternal glands. Tergal and sternal glands are not developed in the physogastric queens, probably, because of a regression process. The development of mandibular glands is similar in swarming females and physogastric queens.

KEY WORDS. Isoptera, glandular system, exocrine glands, histology, physogastric queens, termite
\end{abstract}

The importance and complexity of exocrine gland secretions in social insects have been demonstrated by various authors (WILSON 1965; CRUZ-LANDIM 1996; BUTLER 1967; BILLEN \& MORGAN 1998), but termites have not been so well studied. The role and nature of many glandular secretions still remain unknown mainly among termites (NOIROT 1969; QUENNEDEY 1984; GRASSÉ 1982).

The social organization of the termite colonies depends largely on chemical signals that are produced by several exocrine glands. These glands can be found in all sections of the insect body (BLUM 1985; NOIROT 1969; KAIB \& ZEISMANN 1992).

Some exocrine glands occur in all social insects, as salivary, mandibular, sternal and tergal glands. Termite salivary glands have been investigated in some workers and soldiers and have been found to consist of several thoracic acini and two reservoirs (NOIROT 1969; COSTA-LEONARDO 1987, 1997; COSTA-LEONARDO \& CRUZ-LANDIM 1991). The mandibular glands of termites are cephalic and consist of large peripheral cells and small central ductular cells (NOIROT 1969; CASSIER et al. 1977; COSTA-LEONARDO \& SHIELDS 1990; CONSTANTINO \& COSTA-LEONARDO 1997). The sternal gland of termites is an unpaired organ arising from a thickening of one epidermal sternite, with the exception of Mastotermes Froggatt, 1896 which has three glands (NOIROT 1969, 1995; GRASSÉ 1982). The tergal glands of termites are abdominal structures, found only in some imagoes and sometimes appear to be well developed in both sexes (NOIROT 1969; AMPION \& QUENNEDEY 1981).

This paper shows the histological alterations that occur in the exocrine glands of Cornitermes cumulans (Kollar, 1832) swarming females before and after they become physogastric queens.

1) Departamento de Biologia, Instituto de Biociências, Universidade Estadual Paulista. Caixa Postal 199, 13506-900 Rio Claro, São Paulo, Brasil. E-mail: amcl@rc.unesp.br 


\section{MATERIAL AND METHODS}

Swarming females and physogastric queens of Cornitermes cumulans were collected in the region of Rio Claro (22 $21^{\prime}$ S, $47^{\circ} 31^{\prime} N$ ), São Paulo State, Brazil. Swarming females were collected during the swarming season, wich usually takes place in October and November. Queens with a conspicuous physogastry were obtained from mature field nests. Queens aged 15 days, 7 months and 12 months were obtained from laboratory colonies. In the present study we analyzed three queens of each age and six specimens of swarming females.

The occurrence and morphology of the exocrine glands were determined in histological sections. For histology, the insects were fixed in Bouin or Baker's formaldeyde-calcium for 24 hours, dehydrated in alcohol and embedded in paraffin. Sections were cut to a thickness of 6-7 $\mu \mathrm{m}$, stained with hematoxylin and eosin and analyzed with a Zeiss photomicroscope. The area of the mandibular glands was evaluated in swarming females and physogastric queens using an Axioskop microscope and a computer with an Axioshome system.

\section{RESULTS AND DISCUSSION}

The mandibular and salivary glands of the swarming females and physogastric queens of Cornitermes cumulans exhibit the same developmental pattern when observed in histological sections. However, the tergal and sternal glands showed an evident regression and were not distinct in mature physogastric queens.

\section{Tergal Glands}

The arrangement of tergal glands in swarming females on C. cumulans can be seen in figure 1 . They are conspicuous epidermal glands localized on the last three abdominal segments of these swarming individuals.

The histology of the tergal glands of 15 day old queens is very similar to that observed in swarming females. In seven month old queen, only a thin sheet of glandular cells was observed. Figures 2 and 3 show a cellular thickening corresponding to a glandular region in the $8^{\text {th }}, 9^{\text {th }}$ and $10^{\text {th }}$ tergites.

The tergal glands were not also developed in 12 month old queens and physogastric queens collected in the field. Age polymorphism of exocrine glands also occurs in other social insects and in bees this phenomenon has a fundamental adaptive role (CRUZ-LANDIM 1994).

These glands seem to suffer regression by the time the females grow old and practically disappear in physogastric queens, where only a few glandular cells are present. However, NOIROT (1969), studying the termite Kalotermes flavicollis (Fabricius, 1793), observed that in functionally reproductive pairs of this species, denominated primary king and queen, the height of the tergal gland epithelium decreases and its secretory activity seems to be reduced, although these glands persist and are clearly recognized despite suffering regression. According to GRASSÉ (1984), the queens of Kalotermitidae do not present a true physogastry because they do not produce a new cuticle. Only an infolding of the abdominal cuticle occurs in these queens to accommodate the development of the royal tissue and ovaries. The queens of Termitidae, like mature queens of $C$. cumulans, present real physogastry 

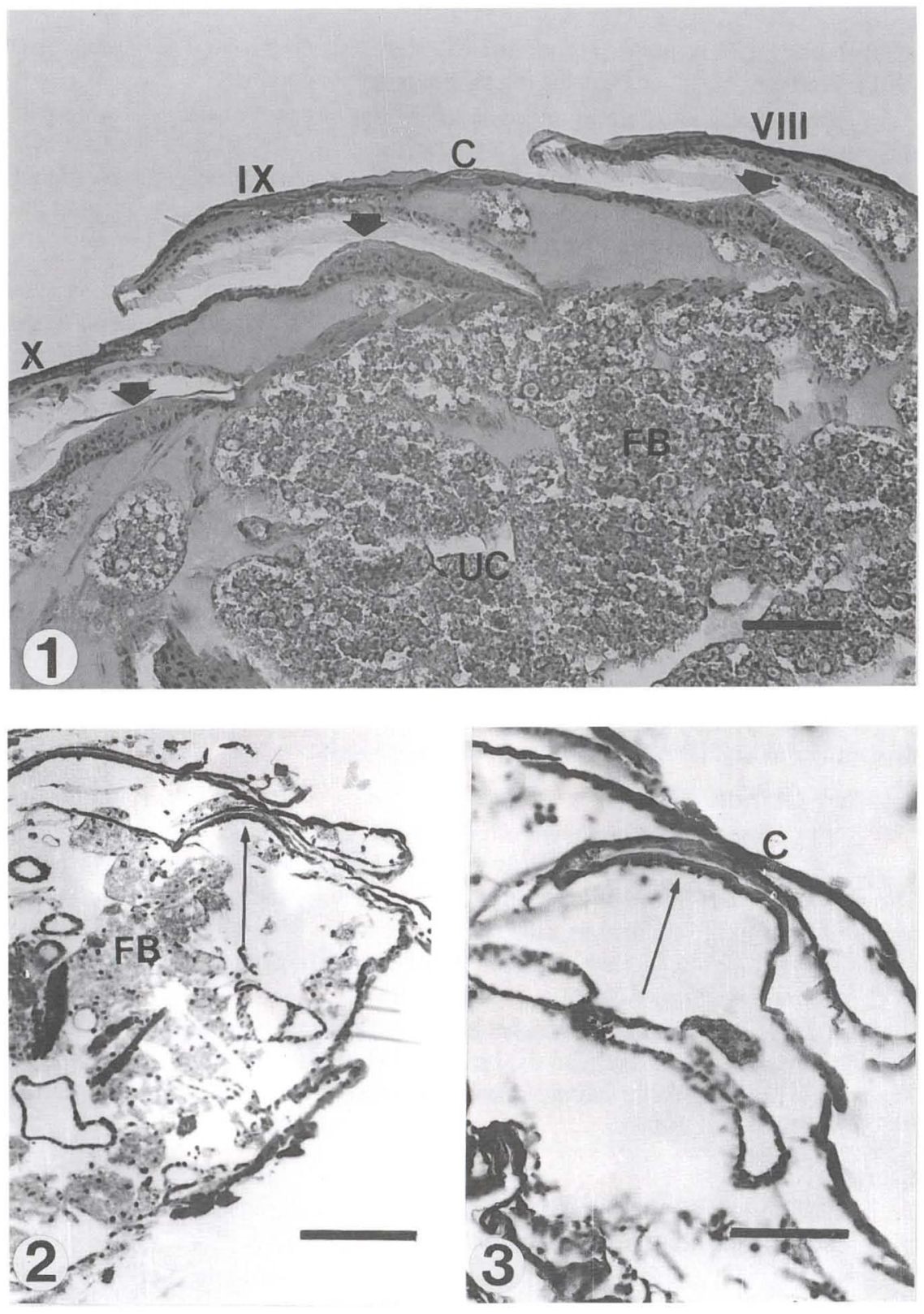

Figs 1-3. Cornitermes cumulans, longitudinal section of the abdomen. (1) In swarming female. The tergal glands can be observed (arrows) on the last three abdominal tergites (VIII, IX and $X$ tergites). (2-3) In seven month old physogastric queen. Note the regression of the tergal glands (arrows). Hematoxylin and Eosin. Scale bars: Fig. $1=50 \mu \mathrm{m}$, Fig. $2=20 \mu \mathrm{m}$, Fig. $3=$ $10 \mu \mathrm{m}$. (C) Cuticle, (FB) fat body, (UC) urate cells. 
and their body suffers intense morphological modifications (NOIROT \& BORDEREAU 1991). Probably, this fact explains the different results obtained.

The tergal glands are involved in the mating process of the swarming pair and enhance their coupling during and after the flight (AMPION \& QUENNEDEY 1981; SRENG 1984). BARTH (1955), studying the termite Syntermes dirus, observed that the removal of the final abdominal segments from swarming female prevented the nuptial dance, and the male became indifferent to the presence of the female.

\section{Mandibular Glands}

The mandibular glands are present in swarming females and queens. They are located inside the head between the maxilla and mandible and seem to have the same development in both insects.

The present histological results indicated that there were no remarkable differences in the size of the glandular area because morphometric comparison of swarming females and physogastric queens showed equivalent mandibular glands (Figs 4 and 5). Morphometric analysis showed that the average glandular area of swarming females and physogastric queens was closely similar $\left(23.300 \mu \mathrm{m}^{2}\right.$ and $22.270 \mu \mathrm{m}^{2}$, respectively).

There are no comparative data on termites about the development of this gland in the reproductive pair, except for observations by COSTA-LEONARDO (unpublished data) showing that the glandular development pattern found in physogastric queens of some species such as Embiratermes festivellus (Silvestri, 1901) was similar to that found for the swarming individuals.

\section{Salivary Glands}

The salivary glands of swarming $C$. cumulans females are located in the thorax and have lobular acini (Fig. 6) formed by basophilic and acidophilic cells. The salivary glands of the physogastric queens have the same morphology as that found in swarming females, as illustrated in figure 7. The salivary glands of the reproductive individuals have the same basic morphological pattern as found in workers of C. cumulans (COSTA-LEONARDO 1987).

The salivary glands of workers have multiple functions and are extremely important when the workers feed the brood, the reproductive pair and the soldiers. In physogastric queens the salivary glands participate in trophallaxis and digestion (KAIB \& ZEISMANN 1992).

\section{Sternal Glands}

The sternal gland is located on the $5^{\text {th }}$ abdominal sternite and is characterized by epidermal thickening (Fig. 8) in swarming $C$. cumulans females.

The sternal gland was not distinct in any of the histological sections of the $5^{\text {th }}$ sternite of $C$. cumulans physogastric queens. This fact suggests a glandular regression in physogastric queens, but this gland, like the tergal glands, consists of a thickening of epidermal cells that becomes limited to few flat cells, when the gland regresses. In 15 days old queens, the sternal gland was present and was easily recognizable, as was the case for swarming females. The sternal gland are not developed in seven and 12 month old queens. 

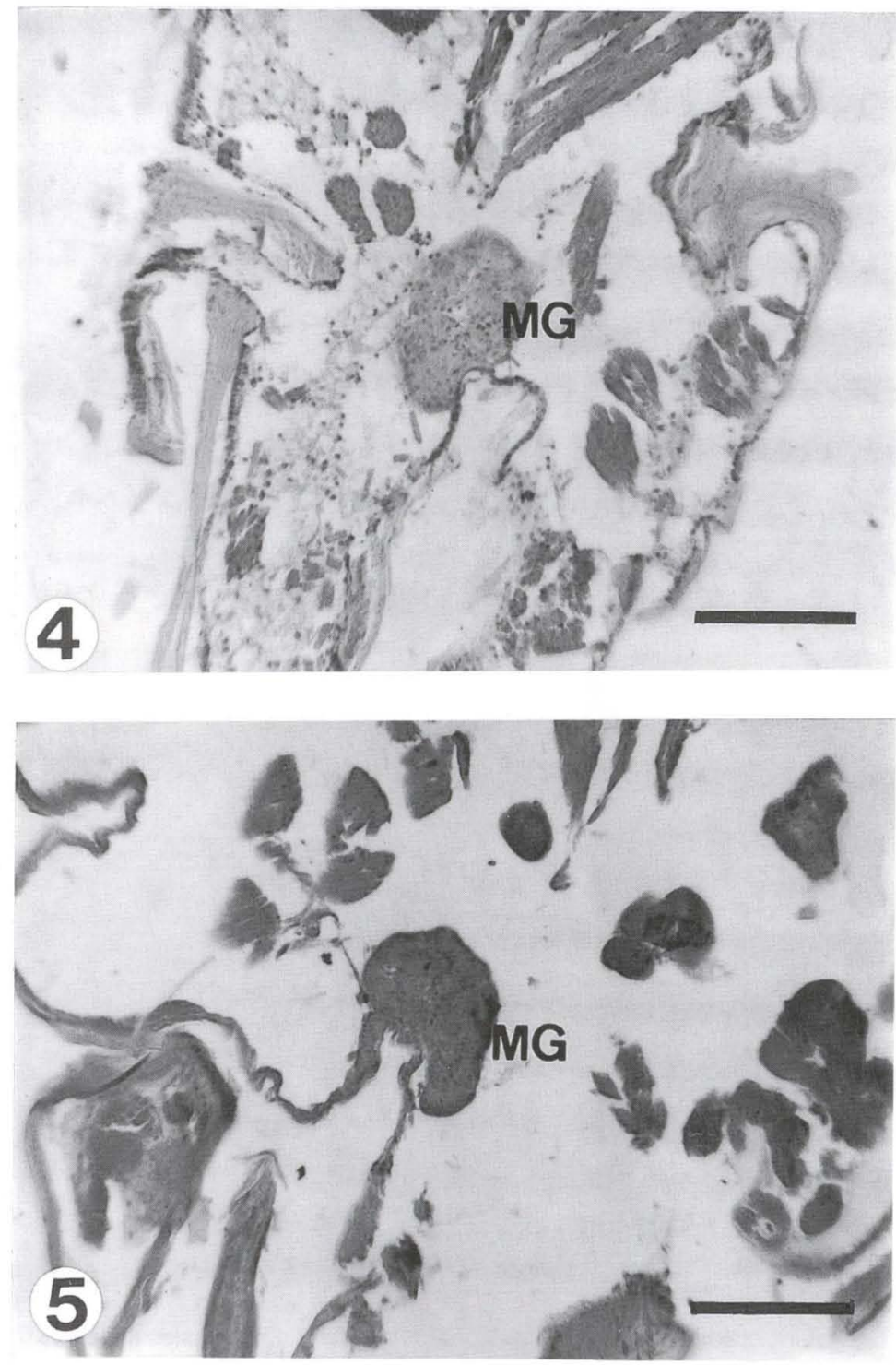

Figs 4-5. Longitudinal sections of the head in swarming female and physogastric queen of Cornitermes cumulans showing the mandibular gland (MG). Hematoxilin and Eosin. Scale bar: $20 \mu \mathrm{m}$.

NOIROT \& NOIROT-THIMOTHÉE (1965) and NOIROT (1995) showed that the position of the sternal glands varies depending on the species. In Mastotermes darwiniensis the three sternal glands are situated in the middle of the $3^{\text {rd }}, 4^{\text {th }}$ and $5^{\text {th }}$ sternites. In all other termite species the sternal gland is a single structure, but is 

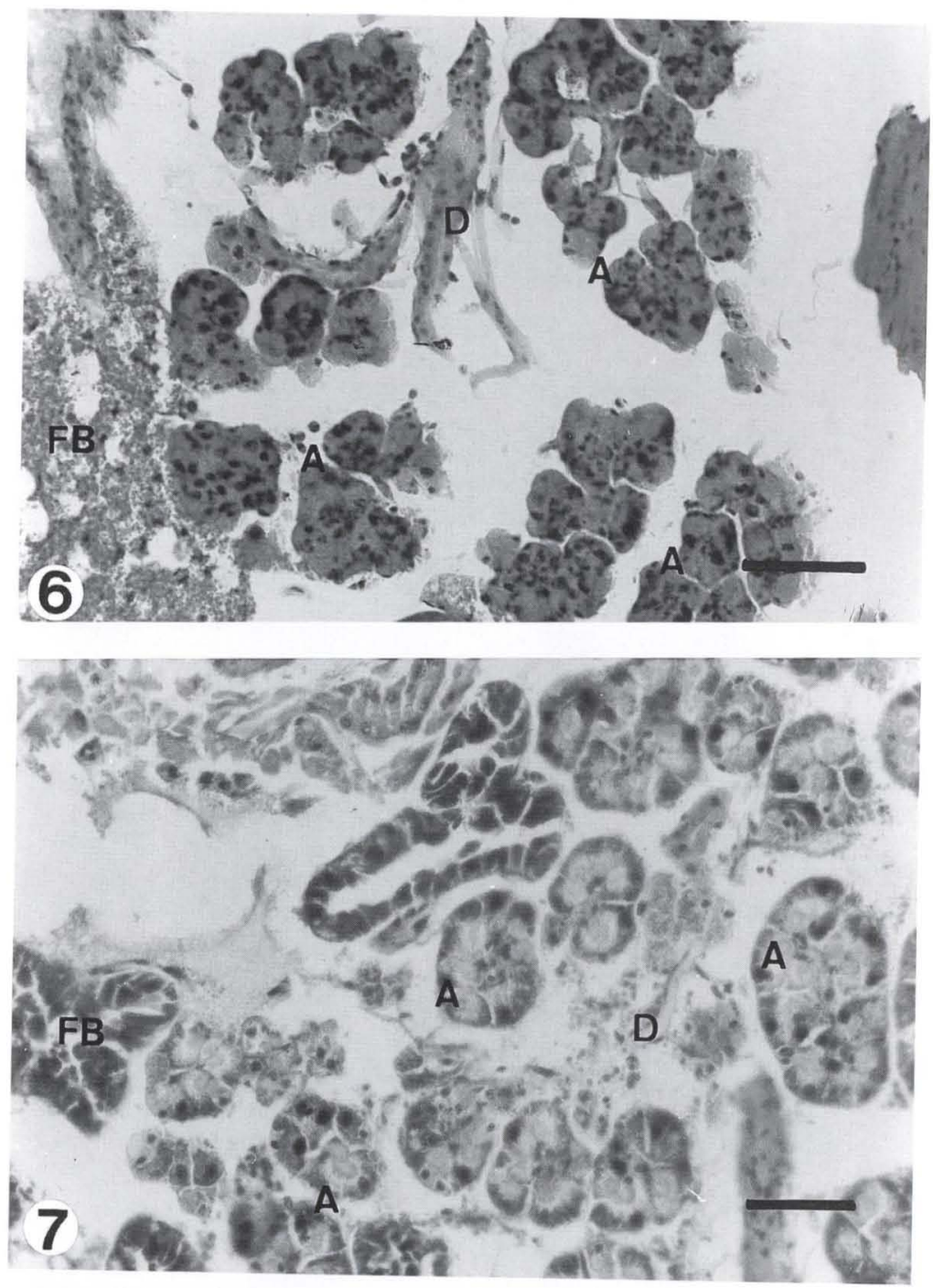

Figs 6-7. Sections of salivary glands in swarming female and physogastric queen of Cornitermes cumulans, respectively. Hematoxylin and Eosin. Scale bars: Fig. $6=10 \mu \mathrm{m}$ and Fig. $7=$ $20 \mu \mathrm{m}$. (A) acini, (D) duct, (FB) fat body.

sometimes located on the anterior part of the $5^{\text {th }}$ sternite (Kalotermitidae, Rhinotermitidae, Serritermitidae and Termitidae) or on the anterior part of the $4^{\text {th }}$ sternite (Hodotermitidae and Termopsidae).

According to NOIROT \& NOIROT-THIMOTHÉE (1965), the sternal gland seems to suffer progressive regression in the functional reproductive pairs of Isoptera. NOIROT \& NOIROT-THIMOTHÉE (1965) and NOIROT (1969) also postulated 


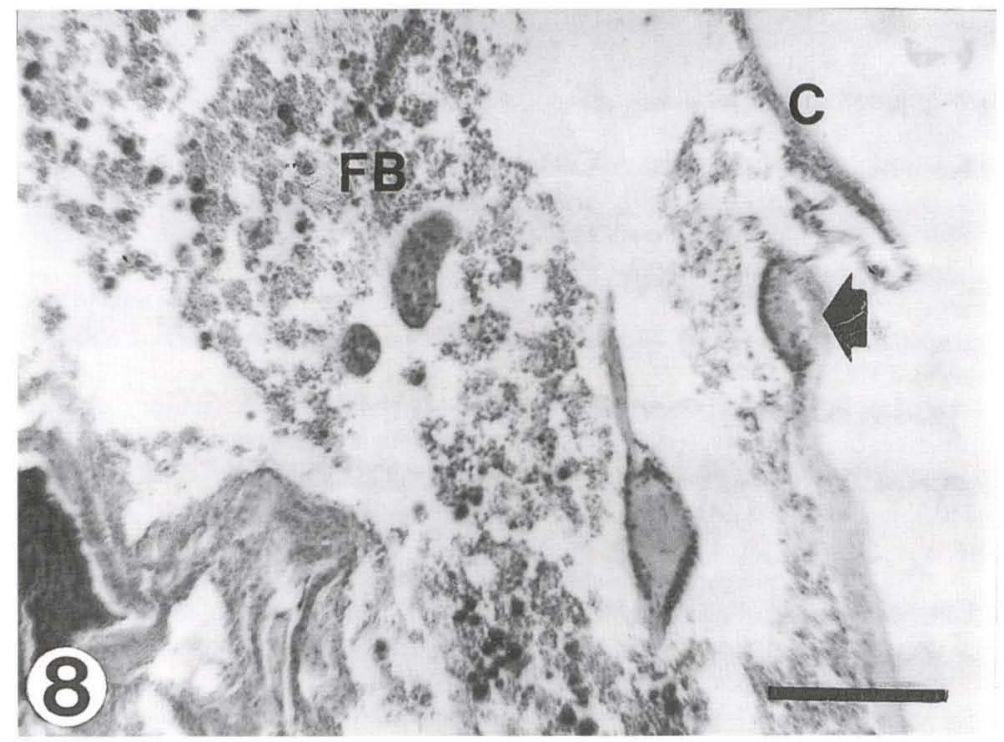

Fig. 8. Longitudinal section of sternal gland (arrow) in swarming female of Cornitermes cumulans. Hematoxylin and Eosin. Scale bar: $20 \mu \mathrm{m}$. (C) cuticle, (FB) fat body.

that in the Nasutitermitinae, the sternal gland is larger in females than in males. These authors studied physogastric queens of Termitidae (Cubitermes fungifaber (Sjostedt, 1896), Procubitermes aburiensis (Sjostedt, 1926) and Microcerotermes sp.) and also suggested that this gland declines in size and it is difficult to identify in older functional reproductive termites.

In agreement with GRASSÉ (1982), who reported regression of the sternal gland of the physogastric queen in the subfamily Nasutitermitinae, the reason for the regression of this gland in $C$. cumulans may have been due to the fact that the gland is responsible for the secretion of female sex pheromones used to attract males in order to start a new colony. After the founding of a new nest, the gland loses its function, and a process of glandular regression begins.

\section{REFERENCES}

AMPION, W. \& A. QuenNEDEY. 1981. The abdominal epidermal glands of termites and their phylognetic significance, p. 249-261. In: P.E. HousE \& J.L. CLÉMENT (Eds). Biosystematics of social insects. London, Academic Press, 346p.

BARTH, R. 1955. Über die tergitalen Drüsenfelder von Syntermes dirus. Rev. Brasil. Biol. 15: 257-263. BILLEN, J. \& E.D. Morgan. 1998. Pheromone communication in social insects: sources and secretions, p. 3-33. In: R.K. vander Meer; M. D. Breed; K.E. Espelie \& M.L. Winston (Eds). Pheromone communication in social insects. London, Westview Press, 230p.

BLuM, M.S. 1985. Exocrine systems, p. 536-579. In: M.S. BLuM \& J. WILEY (Eds). Fundamentals of Insect Physiology. New York, John Wiley \& Sons, 598p.

ButLer, C.G. 1967. Insect pheromones. Biol. Rev. 42: 42-87.

Cassier, P.; M.A. Fain-Maurel \& D. Lebrun. 1977. Electron microscopic study of the mandibular glands of Kalotermes flavicollis Fabr. (Isoptera: Calotermitidae). Cell Tissue Res. 182: 327-330. 
Constantino, R. \& A.M. Costa-Leonardo. 1997. A new species of Constrictotermes from Central Brazil with notes on the mandibular glands of workers (Isoptera: Termitidae: Nasutitermitinae). Sociobiology 30 (2): 213-223.

Costa-Leonardo, A.M. 1987. Morfologia das glândulas salivares de Cornitermes cumulans e Armitermes euamignathus (Isoptera, Termitidae, Nasutitermitinae). Naturalia 11/12: 71-76. . 1997. Secretion of salivary glands of he Brazilian termite Serritermes serrifer (Isoptera, Serritermitidae). Ann. Soc. Entomol. França 33 (1): 29-37.

Costa-Leonardo, A.M; \& K.S. Shields. 1990. Morphology of the mandibular glands in workers of Constrictotermes cyphergaster (Silvestri) (Isoptera: Termitidae). Int. Jour. Insect Morphol. Embryol. 19: 61-64.

Costa-Leonardo, A.M. \& C. Cruz-Landim. 1991. Morphology of the salivary gland acini in Grigiotermes bequaerti (Isoptera: Termitidae: Apicotermitinae). Entomol. Gen. 16 (1): 13-21.

CRUZ-LANDiM, C. 1994. Polimorfismo na ocorrência de glândulas exócrinas nas abelhas (Hymenoptera, Apoidea), p. 118-129. In: Anais do I encontro sobre abelhas. Ribeirão Preto, Univ. São Paulo, $308 \mathrm{p}$.

—. 1996. Glândulas tegumentares abdominais de abelhas. Ocorrência e ultra-estrutura, p. 67-77. In: Anais do II encontro sobre abelhas. Ribeirão Preto, Univ. São Paulo, 351p.

GrassÉ, P.-P. 1982. Termitologia. Paris, Masson, Vol. 1, 676p.

. 1984. Termitologia. Paris, Masson, Vol. 2,613p.

KaIB, M. \& J. ZeISMANn. 1992. The labial gland in the termite Schedorhinotermes lamanianus (Isoptera: Rhinotermitidae): morphology and function during communal food exploitation. Ins. Soc. 39: 373-384.

NoIrot, C. 1969. Glands and secretions, p. 89-123. In: K. KRISHNA \& F. WEESNER (Eds). Biology of termites. New York, Academic Press, Vol. 1, 598p.

1995. The sternal glands of termites: segmental pattern, phylogenetic implications. Ins. Soc. 42: $321-323$.

NoIrot, C. \& C. Bordereau. 1991. Termite polymorphism and morphogenetic hormones, p. 295-324. In: A.P. GUPTA (Ed.). Morphogenetic hormones of arthropods. New Jersey, Rutgers Univ. Press, Vol. 3, 635p.

Noirot, C. \& C. Noirot-Thimothée. 1965. La glande sternale dans l'évolution des termites. Ins. Soc. 12 (3): $265-272$.

QuenNEDEY, A. 1984. Morphology and ultrastructure of termite defence glands, p. 151-200. In: H.R. Hermann (Ed.) Defensive mechanisms in social insects. New York, Praeger Press, 259p.

SRENG, L. 1984. Morphology of the sternal and tergal glands producing the sexual pheromones and aphrodisiacs among the cockroaches of the subfamily Oxyhalionae. Jour. Morphol. 182: 279-294.

WILSON, E.O. 1965. Chemical communication in the social insects. Science 149: 1064-1071.

Recebido em 21.IX.2000; aceito em 10.IX.2001. 